\title{
KNOWLEDGE, ATTITUDE AND PRACTICE OF HEALTH CARE PROVIDERS REGARDING COVID-19 IN PAKISTAN
}

\section{ABSTRACT}

This observational study was conducted to assess the attitude, knowledge and practices of health-care providers in context of novel corona virus or COvid-19 in Pakistan. A cross sectional survey has been conducted among the physicians, dentists, physiotherapists, pharmacists and nurses in a number of medical and health related facilities of Pakistan from April to June 2020. A self-constructed questionnaire was used among the 277 health care providers and SPSS version 23 was used to analyze the data. Male participants constituted $55.6 \%(n=154)$ of the total sample size. However, $91 \%$ of total participants aged between 23 to 33 years $(n=252)$. In addition to this $71 \%$ participants were unmarried. In academic perspective $74.4 \%$ of the candidates were graduates and most of them were MBBS. Around $46.6 \%$ people were permanent residents of Sindh while others belong to different regions of the country. Assessment revealed of knowledge, attitude and practice results showed that the great majority i.e. $96 \%(n=266)$ of the healthcare providers had adequate knowledge with respect to Covid-19. Moreover, $59.2 \%$ people $(n=164)$ demonstrated positive attitude towards covid-19. Contrastingly, practices of a large number of healthcare providers were not found appropriate that makes up to $57.4 \%(n=159)$. The study concluded that the health care providers working in Pakistan have good knowledge and positive attitude towards covid-19, whereas the practice of Pakistani health care providers needs serious attention, because the results reveled the practice is below the mark.

\section{Keywords:}

Knowledge, Attitude, Practice, Covid-19, Healthcare Professionals.
Aadil Ameer Ali

Lecturer

Institute of Physiotherapy \& Rehabilitation Sciences,

Shaheed Mohtarma Benazir Bhutto Medical University, Larkana, Pakistan. aadilamirali@hotmail.com

Noman Haq

Professor

Faculty of Pharmacy \&

Health Sciences,

University of Balochistan,

Quetta, Pakistan

nomanhaq79@gmail.com

Muhammad Rafiq,

Lecturer

Department of Statistics, University of Sindh, Jamshoro, Pakistan. doudpoto.rafique@usindh. edu.pk

Amjad Hussain,

Lecturer

Faculty of Pharmacy \&

Health Sciences,

University of Balochistan, Quetta, Pakistan amjadkhattak333@gmail.co $\underline{\mathrm{m}}$

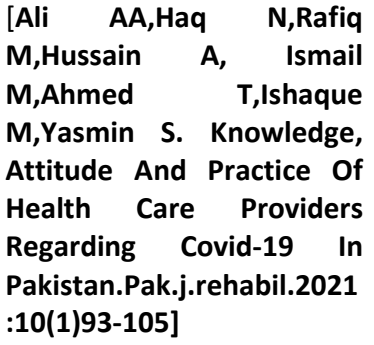

DOI;

10.36283/pjr.zu.10.1/013 


\section{INTRODUCTION}

In December 2019, a highly transmittable novel corona virus (abbreviated "COVID$19^{\prime \prime}$ ) outbreak is found in seafood market of Wuhan (Hubei, China), among the group of patients who went to hospital with the sudden complain of cough, sore throat, fever, myalgia (muscular pain) which are the common symptoms for COVID-19, while occasional gastrointestinal symptoms, acute respiratory distress syndrome (ARDS), unclassified viral pneumonia (unknown etiology) and even death was observed in severe cases $^{1-6}$. Although in the symptoms of COVID-19 little variation were found and Some patients were found asymptomatic as well ${ }^{2,6-7}$. Children's, older individuals and the persons who are suffering from any chronic disease are more vulnerable to COVID-19 $9^{7-8}$. Initially, The Asian civet cat (Paguma larvata) were identified as the carrier of COVID-19 virus 9-10. However, human to human transmission of COVID-19 takes place through the contact of contaminated surfaces; and by catching the tiny droplets produced while coughing, sneezing and talking of COVID-19 infected persons that may can remain viable in the air up to 72 hours $^{2,5,10-12}$. Although the COVID-19 is new and communicable disease, the only way of prevention is the protection of susceptible individuals ${ }^{2,13}$.

Globally, COVID-19 took less than 30 days, to spread across the growing countries since it was first reported at Wuhan, China ${ }^{1,}{ }^{14}$. Moreover, In the end of January 2020, a public health emergency has been declared by world health organization (WHO) due to the frequent spread to COVID-19 and in the mid of March 2020 it is declared as pandemic ${ }^{6,15}$. Uptill the date of writing, COVID-19 has reached up to $2.9 \%$ of mortality rate across the world ${ }^{10}$. About half millions of cases with the conformed diagnosis of COVID-19 have been reported from all over the world ${ }^{15}$. While, in Pakistan more than one thousand cases of COVID-19 had been reported, till the end of March 2020 4,15 .

Health care providers (HCP) are practically the first line defense as well as the front line fighters not only in prevention but also in care and management of infected person, therefore, their knowledge regarding any highly transmittable and pandemic disease like (COVID-19) play a vital role in order to decrease the spread of diseases, and understanding the influence of attitude and practices on the spread of diseases can be crucial in improving prevention and controlling of that disease ${ }^{16-18}$. Concluding to this, there is a need to evaluate the knowledge, attitudes and practices among health care providers of Pakistan in context of Covid19.

\section{METHODOLOGY}

\section{Study Design}

This study was a cross-sectional survey.

\section{Study Duration}

This study was conducted from April 2020 to June 2020 .

\section{Study Setting}

Data was collected from the health care providers including doctors, dentists, physiotherapists, pharmacists and nurses working at various hospitals and health care facilities all over Pakistan. Convenience sampling technique was used to recruit the participants.

A sample of 277 participants was recruited from the healthcare providers agreed to participate in the study. Participant who were working in hospitals as a health care providers including doctors, dentists, physiotherapists, 
pharmacists, nurses who are agreed to participate were included. However, those participants who refuse to the sign inform consent was not enrolled.

\section{Data Collection Tool}

A self-designed questionnaire was generated for the collection of data, consisting of two sections; first is comprising of demographics information such as age, gender, matrimonial status, level of education, specialty and province of present residence while second sections contains questions that were integrated to assess the attitudes, knowledge and practices (KAP) by pursuing the recommendations given by the Chinese National Health Commission for clinical and community administration of COVID-19 outbreak ${ }^{8,13}$. The author developed the questioner that consist of total 26 different questions (Knowledge=11, Attitude=04, Practice $=10$ ).

\section{Data Collection Procedure}

The data was collected online through electronic or e-questionnaire. The link of e- questionnaire was send to the health care providers through e-mails, WhatsApp and other popular social media applications.

\section{Data Analysis Procedure}

Version 2.0 of SPSS was used to perform data analysis. All the categorical variables were analyzed and presented in terms of frequency and percentiles. In addition to this, mean and standard deviations were presented for continuous variables. Inferential statistics were driven by performing person correlation to find out the association between Knowledge attitude and practice.

Ethical Consideration: The ethical review committee of respective institution was requested to grant permission for the research project. Moreover, an informed consent was taken from all the participants to maintaining that their participation is voluntary, and their information provided by them shall be kept confidential. Furthermore, participants were given the full right to cease their participation form the study at any time.

\section{RESULTS}

The study was conducted to assess the knowledge, attitude and practices regarding Covid19 among the health care providers of Pakistan. Descriptive statistics revealed that 55.6 percent participants were male while 54.4 percent were female. However, the large number of the participants unanimously belongs to the age bracket of 23-33 years making up 91 percent of the total sample size. Moreover, 71 percent of the participant were unmarried $(n=197)$ and 46 percent of them were residing in the province of Sindh. Further demographic details are expressed in table 1 


\begin{tabular}{|c|c|c|}
\hline \multicolumn{3}{|c|}{ Table-1 Demographics of participants } \\
\hline Characteristics & Frequency & Percentage \\
\hline $\begin{array}{l}\text { Age group } \\
23-33 \text { years }\end{array}$ & 252 & 91 \\
\hline 34-44 years & 21 & 7.6 \\
\hline 45 and above & 4 & 1.4 \\
\hline \multicolumn{3}{|l|}{ Gender } \\
\hline Male & 154 & 55.6 \\
\hline Female & 123 & 44.4 \\
\hline \multicolumn{3}{|l|}{ Marital status } \\
\hline Married & 80 & 28.9 \\
\hline Unmarried & 197 & 71.1 \\
\hline \multicolumn{3}{|l|}{ Education } \\
\hline Graduate & 206 & 74.4 \\
\hline Post-graduate & 70 & 25.3 \\
\hline Doctorate & 1 & 0.4 \\
\hline \multicolumn{3}{|l|}{$\begin{array}{l}\text { Specialty } \\
\text { (Major) }\end{array}$} \\
\hline MBBS & 98 & 35.4 \\
\hline BDS & 17 & 6.1 \\
\hline DPT & 71 & 25.6 \\
\hline Pharm-D & 19 & 6.9 \\
\hline $\begin{array}{l}\text { Eastern } \\
\text { Medicine }\end{array}$ & 57 & 20.6 \\
\hline Other & 15 & 5.4 \\
\hline \multicolumn{3}{|l|}{$\begin{array}{l}\text { Province of } \\
\text { current } \\
\text { residence }\end{array}$} \\
\hline Sindh & 129 & 46.6 \\
\hline Punjab & 53 & 19.1 \\
\hline Balochistan & 76 & 27.4 \\
\hline Kpk & 13 & 4.7 \\
\hline Islamabad & 6 & 2.2 \\
\hline $\begin{array}{l}\text { Azad and } \\
\text { Jammu Kashmir }\end{array}$ & 0.0 & 0.0 \\
\hline
\end{tabular}




\section{Assessment of Knowledge towards}

\section{COVID-19}

Knowledge was appraised by the questions focusing on the sign \& symptoms, mode of transmission and prevention strategy. Each response was consisting of "Yes" and "No" where the "yes" was assigned 1 score and "No" with 0 . The maximum score on the scale of knowledge questionnaire was (11) while minimum was zero. Similarly, 6 and scores below were counted as in-adequate knowledge; however, score of 7 and above was graded to adequate knowledge. All the individual scores were summed up to calculate the total score. Out of 277 participants, ( $n=11,4 \%$ ) were within the scale of inadequate knowledge, whereas ( $n=266,96 \%)$ were found in scale of adequate knowledge regarding COVID19. poor knowledge was observed in the response of question relating to symptoms (question 1-4), mode of transmission of COVID-19 (question 5-7) and prevention strategy (question 8-11). The frequency of the respondent correctly answered these questions was $84.5,70$, 96 and $66.4 \%$ for symptoms while 51.3 , $87.4,98.9$ and $81.9 \%$ for the mode of transmission respectively. Whereas the correct answer for the prevention strategies were $81.9,53.8,97.5$ and $97.8 \%$ as demonstrated in table 2 . 
Table 2: Response to COVID-19 Knowledge items

\begin{tabular}{|c|c|c|}
\hline COVID-19 Knowledge item & $\begin{array}{c}\text { Yes } \\
\text { N (\%) }\end{array}$ & $\begin{array}{c}\text { No } \\
\text { N (\%) }\end{array}$ \\
\hline $\begin{array}{l}\text { Do you agree that the major clinical symptoms of coronavirus } \\
\text { (COVID-19) are fever, fatigue, dry cough, and muscular pain } \\
\text { (myalgia)? }\end{array}$ & $234(84.5)$ & $43(15.5)$ \\
\hline $\begin{array}{l}\text { Disparate the usual cold, nasal congestion, runny nose (rhinorrhea), } \\
\text { and sneezing are not common in patients suffering from COVID-19 } \\
\text { virus. }\end{array}$ & 194(70) & $83(30)$ \\
\hline $\begin{array}{l}\text { Currently there is no effectual remedy for COVID-19, but initial } \\
\text { symptomatic and suggestive treatment may help majority patients } \\
\text { recover from the infection. }\end{array}$ & $266(96)$ & $11(4)$ \\
\hline $\begin{array}{l}\text { Not all patients with COVID-19 will go down with severe cases. } \\
\text { Patients who are elderly, suffering from chronic disease including } \\
\text { obesity are more prone to be severe cases. }\end{array}$ & $184(66.4)$ & $93(33.6)$ \\
\hline $\begin{array}{l}\text { Eating or exposure to wild pets would responsible to get infected by } \\
\text { the COVID-19 virus. }\end{array}$ & $142(51.3)$ & $135(48.7)$ \\
\hline $\begin{array}{l}\text { Persons with COVID-19 may not spread the virus among others when } \\
\text { a fever is absent }\end{array}$ & $35(12.6)$ & $242(87.4)$ \\
\hline $\begin{array}{l}\text { The COVID-19 virus spreads through the respiratory droplets of } \\
\text { infected patient }\end{array}$ & $274(98.9)$ & $03(1.1)$ \\
\hline $\begin{array}{l}\text { In current outbreak of COVID-19, for children and young adults is it } \\
\text { not obligatory to take safety initiatives to prevent the infection? }\end{array}$ & $50(18.1)$ & $287(81.9)$ \\
\hline $\begin{array}{l}\text { To prevent the infection by COVID-19, health-care providers ought } \\
\text { ignore visiting to crowded locations like train stations and ignore } \\
\text { using public transportation }\end{array}$ & $149(53.8)$ & $128(46.3)$ \\
\hline $\begin{array}{l}\text { Isolation and medication of patients who are suffering with the } \\
\text { COVID-19 virus are potent methods to decrease the span of COVID- } \\
19 .\end{array}$ & $270(97.5)$ & $07(2.5)$ \\
\hline $\begin{array}{l}\text { Health-care providers having contact with patient suffering from the } \\
\text { COVID-19 virus ought to be isolated in a specific place. Generally, the } \\
\text { observation period is } 14 \text { days. }\end{array}$ & $271(97.8)$ & $06(2.2)$ \\
\hline
\end{tabular}


Assessment of Attitude towards COVID19

The responses expressing the attitude of respondents towards COVID-19 are shown in table 3. The attitude (positive \& negative) was appraised with the help of four questions. In attitude there was score of maximum (4) and minimum (0), a score of 1 was assign to positive attitude, and 0 to negative attitude. The score of 2 and below assumed as negative attitude whereas 3 and above for positive attitude. The total score was compute by summing up the scores individually. Out of 277 participants 164 (59.2\%) showed a positive attitude, whereas attitude of 113 (40.8\%) was identified as negative. Majority ( $n=180,97 \%)$ of participants were hoped that the COVID-19 will be controlled successfully. While, $(n=168$, 60.7) of people state that the Pakistan is not able to introduce the proper treatment to cure the COVID-19. In addition, ( $n=190,68.6 \%$ ) of people had a confidence that they will win the battle against the COVID-19. Although $(n=230$, $83 \%)$ of participants updated their knowledge regarding COVID-19 since last month.

Table 3: Response to COVID-19 Attitude items

COVID-19 Attitude item
Do you admit that COVID-19 will eventually be controlled?
Do you admit that Pakistan is able to introduce the proper treatment
to cure the COVID-19?

Do you have trust that Pakistan may successfully achieve the victory in case of COVID-19 virus?

190(68.6) $87(31.4)$

Did you update your knowledge at least for once regarding the COVID-19 since last month?

\begin{tabular}{cc} 
Yes & No \\
$\mathbf{N}(\%)$ & $\mathbf{N}(\%)$ \\
\hline $180(65)$ & $97(35)$ \\
\hline $109(39.3)$ & $168(60.7)$
\end{tabular}

\section{Assessment of Practice towards COVID-} 19

The practice of healthcare providers is graded as "good" or "bad" through an appraisal consisting of 10 questions. Each response consists of "Yes" and "No" where the "yes" was assigned 1 score and "No" with 0 . The maximum score on the scale of practice questionnaire was 10 while zero was considered minimum. Moreover, 6 and scores below were assumed as bad practice while 7 and above were coined as good practice. The total score was calculated by summing up the scores individually. Unfortunately, 159 (57.4 \%) out of 277 participants, were identified for mal-practice, whereas 118 $(42.6 \%)$ were graded as good practice. Majority ( $n=239,8.3 \%)$ of participants took all necessary precautionary measures at their workplaces towards
COVID-19 and $(n=216,78 \%)$ took personal initiative to prevent the infection (COVID19). Among all participants ( $n=142,51.2 \%)$ isolated themselves from their families. However, it was evident that majority of healthcare providers were not taking precautions serious such as 246 (88.8\%) of participants were going to crowded places, although, much of these people ( $n=260,93.9$ ) were wearing mask when they were leaving home. The $(n=248$, $89.5 \%$ ) of participants were washing their hands for 20 seconds. Among all, ( $n=143$, $51.6 \%)$ of participants were mark themselves able to identify the suspected patient of COVID-19. In addition, ( $n=160$, $57.8 \%)$ of participants received the personal protective equipment (PPE) from their respective hospital, and $(n=220$, 79.4) had not seen any patient of COVID19 as further expressed in table 4; 


\begin{tabular}{|c|c|c|}
\hline COVID-19 Practice item & $\begin{array}{l}\text { Yes } \\
\mathbf{N}(\%)\end{array}$ & $\begin{array}{c}\text { No } \\
\mathbf{N}(\%)\end{array}$ \\
\hline $\begin{array}{l}\text { Being a health care provider, do you take all precautionary measures } \\
\text { at your workplace for COVID-19 virus? }\end{array}$ & 239(86.3) & $38(13.8)$ \\
\hline $\begin{array}{l}\text { To prevent the infection by COVID-19, being a healthcare provider } \\
\text { do you take any personal initiative? }\end{array}$ & $216(78)$ & $61(22)$ \\
\hline $\begin{array}{l}\text { To prevent the infection by COVID-19, a health care provider should } \\
\text { keep himself isolated from his / her family. }\end{array}$ & $142(51.2)$ & 135(48.8) \\
\hline In current situation, have you visited any crowded location? & $31(11.2)$ & $246(88.8)$ \\
\hline $\begin{array}{l}\text { In current situation, have you worn a mask particularly when getting } \\
\text { out of home? }\end{array}$ & 260(93.9) & 17(6.1) \\
\hline Do you wash your hands for 20 seconds regularly? & $248(89.5)$ & $29(10.5)$ \\
\hline Do you encounter any patient who is suspect to COVID-19? & $50(18.1)$ & $227(81.9)$ \\
\hline Are you able to identify the suspected patients of COVID-19? & $143(51.6)$ & $134(48.4)$ \\
\hline $\begin{array}{l}\text { Does your hospital provided you the personal protective equipment } \\
\text { (PPE)? }\end{array}$ & $117(42.2)$ & $160(57.8)$ \\
\hline Have you seen any patients of COVID-19? & $57(20.6)$ & $220(79.4)$ \\
\hline $\begin{array}{l}\text { Assessing Overall Knowledge, Attitude } \\
\text { and practice, it was revealed that the } \\
\text { health care providers demonstrated good }\end{array}$ & $\begin{array}{l}\text { positive } \\
\text { found to } b \\
\text { urther shou }\end{array}$ & $\begin{array}{l}\text { attitude, } \\
\text { involved }\end{array}$ \\
\hline
\end{tabular}

Table 5: Overall Knowledge, Attitude and practice

\begin{tabular}{lccc}
\hline & & Good knowledge $\mathbf{n}(\%)$ & Poor knowledge $\mathbf{n}(\%)$ \\
\hline $\begin{array}{l}\text { Knowledge (mean } \\
\text { 8.86) }\end{array}$ & score & $266(96)$ & $11(04)$ \\
\hline & & Positive Attitude $\mathbf{n}(\%)$ & Negative Attitude $\mathbf{n}(\%)$ \\
Attitude (mean score 2.61) & $164(59.2)$ & $113(40.8)$ \\
\hline & Good Practice $\mathbf{n}(\%)$ & Bad Practice $\mathbf{n}(\%)$ \\
Practice (mean score 5.18) & $118(42.6)$ & $159(57.4)$ \\
\hline
\end{tabular}

The cut of score for the knowledge was $\leq 6$, Attitude $\leq 2$ and for practice $\leq 6$. 
Figure 1: Overall Knowledge, Attitude and Practices of Healthcare providers

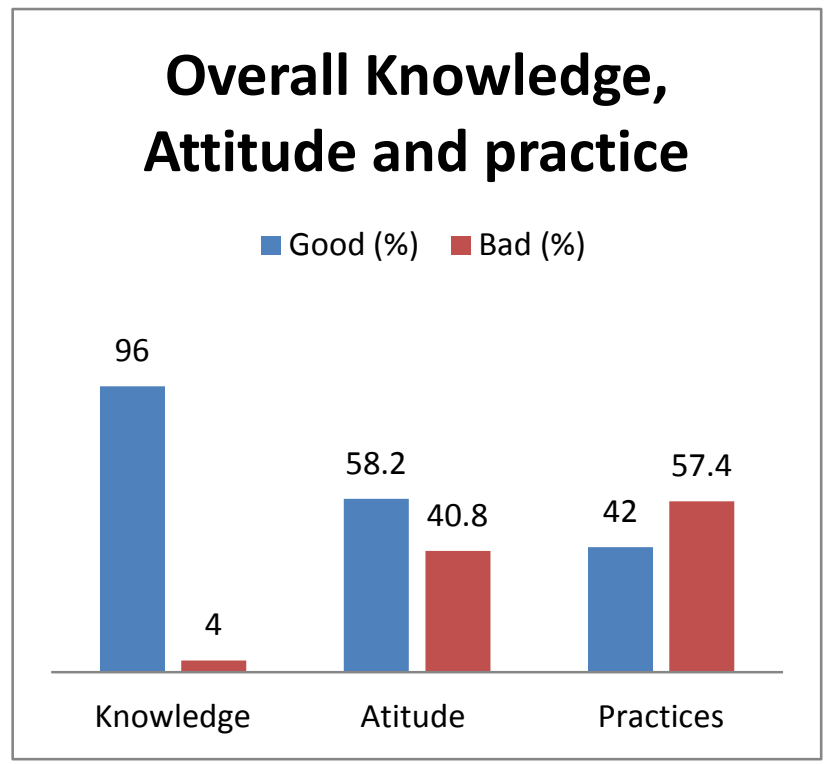

\section{Correlation between Knowledge, Attitude, and Practice Scores}

Pearson correlation was run to find out the correction between the knowledge, attitude and practices of healthcare providers, which releveled significant positive correlation between knowledgeattitude $(r=0.245, p<0.001)$ and attitudepractice $(r=0.121, p<0.44)$. The results conform the positive relationship between knowledge-attitude and attitude-practice against the COVID-19 as further illustrated in table 6 and figure 2;

Table 6: Correlation between knowledge, attitude, and practice scores

\begin{tabular}{lcc}
\hline Variable & $\begin{array}{c}\text { Correlation } \\
\text { coefficient }\end{array}$ & P-value \\
\hline \hline $\begin{array}{l}\text { Knowledge- } \\
\text { Attitude** } \\
\text { Knowledge- } \\
\text { Practice }\end{array}$ & 0.245 & 0.001 \\
$\begin{array}{l}\text { Attitude } \\
\text { Practice* }\end{array}$ & 0.100 & 0.095 \\
\hline
\end{tabular}

* Correlation is significant at the 0.05 level (2-tailed)
** correlation is significant at the 0.01 level (2-tailed)

Figure 2; Correlation between Knowledge, Attitude and Practices with $\mathrm{p}$ - values

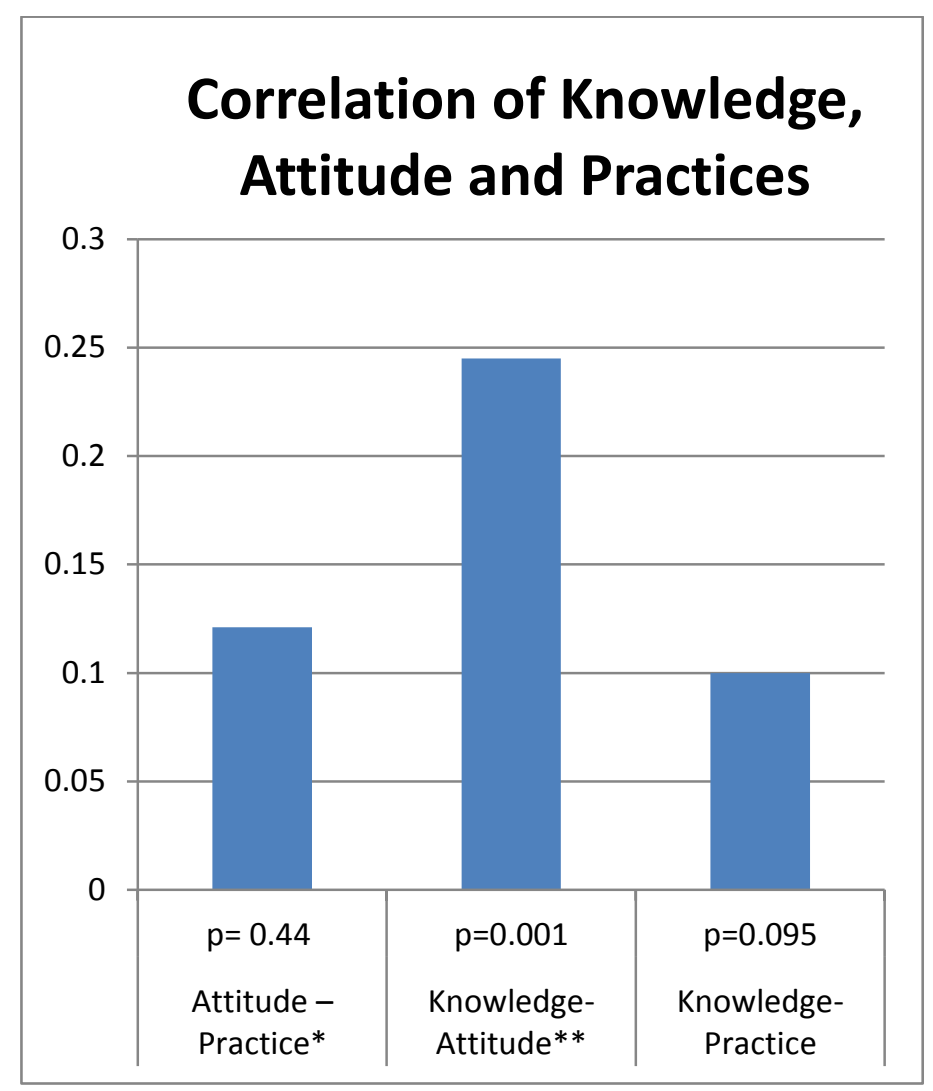

\section{Discussion}

The current study was conducted to appraise the knowledge, attitude and practice (KAP) towards COVID-19 among the health care providers (HCPs) of Pakistan, which revealed that they had sound knowledge and positive attitude towards COVID-19, but unfortunately bad practice was observed among them. Among all $(n=277)$ participants, the $57.4 \%$ were doing bad practice towards COVID19 such as visiting over crowded places.

As a matter of fact, majority of HCPs were involved in bad practice unintentionally, because of not being provided the personal protective equipment's (PPE) by their respective hospitals as highlighted by Polly Pallister-Wilkins in 2016, which concluded that, use of PPE is necessary for saving the life of patients in different outbreak of infectious diseases 19. 
Similarly, studies were conducted by Fischer et al in 2014, Chia et al in 2005, Tomas et al in 2015, Adams et al in 2020 and Maclntyre et al in 2015 that to reduce the exposure of infectious diseases like COVID-19 which is highly transmittable and could be nosocomial, it's necessary to provide the sufficient number and upgraded gears of personal protection to $\mathrm{HCPs}^{20-26}$.

Moreover, it's important to observe that, different studies were reported from united states and concluded that because of the infectious nature and outbreak situations, COVID-19 can be associated with noteworthy fear of getting selfinfected which also can be the leading cause of bad practice among the HCPs ${ }^{27-}$ 28.

Furthermore, conducted in united states of America by Gery \& Gloria in 1989, Burns et al in 2012, Barone et al in 2009, Oladimeji et al., 2015 in Nigeria and Alanazi et al in 2014 in Saudi Arabia and concluded that due to the in-adequate training of HCPs regarding the disease outbreak like COVID-19, discrepancies were prevailed among $\mathrm{HCPs}^{29-33}$. In addition to this, government should increase the scores of practice by enhancing the efficacy and number of concerned trainings by which HCPs learn, how to tackle and integrate the outbreak of such diseases ${ }^{34-37}$.

On contrary, in rural areas the suboptimal health care facilities regarding COVID-19 were observed along with the bad practice of HCPs $36,38-41$. Finally, the Implementation of good practice needs sufficient sources, good management and a nice planning from the government is required on urgent basis ${ }^{42}$.

Surprisingly, the study revealed that the overall knowledge of health care providers is good with positive attitude. However, they could not incorporate the good knowledge and positive attitude into good practices. Inclusively, the major reason could acute encounter of this type of pandemic which was never experienced previously by at least the current living generation of HCPs. Similarly, the health care setups lack basic facilities with regards to protection. Moreover, HCPs were not been trained properly to combat this type of situation so proper training and provisions of protection facilities will unable health care providers to incorporate the knowledge and positive attitude to fight against this pandemic.

\section{Conclusion}

The study concluded that the majority of health care providers, despite having adequate knowledge and positive attitude were involved in "bad" practice towards COVID-19 due to the fear of getting selfinfected, lack of training, personal protective equipment's and suboptimal health care facilities in Pakistan. However, positive correlation suggests that more knowledge and awareness could possibly improve the practices of HCPs.

\section{References}

[1] Novel CPEREJZlxbxzzZlz. The epidemiological characteristics of an outbreak of 2019 novel coronavirus diseases (COVID-19) in China. 2020;41(2):145.

[2] Bai Y, Yao L, Wei T, Tian F, Jin D-Y, Chen $L$, et al. Presumed asymptomatic carrier transmission of COVID-19. 2020.

[3] Chen H, Guo J, Wang C, Luo F, Yu X, Zhang $W$, et al. Clinical characteristics and intrauterine vertical transmission potential of COVID-19 infection in nine pregnant women: a retrospective review of medical records. 2020;395(10226):809-15.

[4] Liu Y, Gayle AA, Wilder-Smith A, Rocklöv JJJotm. The reproductive 
number of COVID-19 is higher compared to SARS coronavirus. 2020.

[5] Xu Z, Shi L, Wang Y, Zhang J, Huang L, Zhang $C$, et al. Pathological findings of COVID-19 associated with acute respiratory distress syndrome. 2020.

[6] Wu Y-C, Chen C-S, Chan Y-JJJotCMA. The outbreak of COVID-19: An overview. 2020;83(3):217-20.

[7] Rothan HA, Byrareddy SNJJoA. The epidemiology and pathogenesis of coronavirus disease (COVID-19) outbreak. 2020:102433.

[8] Jin $\mathrm{Y}-\mathrm{H}$, Cai L, Cheng Z-S, Cheng $\mathrm{H}$, Deng $T$, Fan $Y-P$, et al. A rapid advice guideline for the diagnosis and treatment of 2019 novel coronavirus (2019-nCoV) infected pneumonia (standard version). 2020;7(1):4.

[9] Peeri NC, Shrestha N, Rahman MS, Zaki R, Tan Z, Bibi S, et al. The SARS, MERS and novel coronavirus (COVID19) epidemics, the newest and biggest global health threats: what lessons have we learned? 2020.

[10] Shereen MA, Khan S, Kazmi A, Bashir $\mathrm{N}$, Siddique RJJoAR. COVID-19 infection: origin, transmission, and characteristics of human coronaviruses. 2020.

[11] Whitworth JJToTRSoTM, Hygiene. COVID-19: a fast evolving pandemic. 2020.

[12] van Doremalen $N$, Bushmaker $T$, Morris DH, Holbrook MG, Gamble A, Williamson $\mathrm{BN}$, et al. Aerosol and surface stability of SARS-CoV-2 as compared with SARS-CoV-1. 2020.

[13] Shen K, Yang Y, Wang T, Zhao D, Jiang $Y$, Jin $R$, et al. Diagnosis, treatment, and prevention of 2019 novel coronavirus infection in children: experts' consensus statement. 2020:19.

[14] Dong E, Du H, Gardner LJTLid. An interactive web-based dashboard to track COVID-19 in real time. 2020.
[15] Organization WH. Coronavirus disease 2019 (COVID-19): situation report, 67. 2020.

[16] Bakry S, Mustafa A, Eldalo AS, Yousif MJIJoR, Medicine Si. Knowledge, attitude and practice of health care workers toward Hepatitis B virus infection, Sudan. 2012;24(2):95-102.

[17] Gulilat K, Tiruneh GJSjoph. Assessment of knowledge, attitude and practice of health care workers on infection prevention in health institution Bahir Dar city administration. 2014;2(5):38493.

[18] Shi Y, Wang J, Yang Y, Wang Z, Wang $G$, Hashimoto $K$, et al. Knowledge and attitudes of medical staff in Chinese psychiatric hospitals regarding COVID19. 2020:100064.

[19] Pallister-Wilkins PJTWQ. Personal Protective Equipment in the humanitarian governance of Ebola: between individual patient care and global biosecurity. 2016;37(3):507-23.

[20] Fischer WA, Hynes NA, Perl TMJAoim. Protecting health care workers from Ebola: personal protective equipment is critical but is not enough. 2014;161(10):753-4.

[21] Tomas ME, Kundrapu S, Thota $P$, Sunkesula VC, Cadnum JL, Mana TSC, et al. Contamination of health care personnel during removal of personal protective equipment. 2015;175(12):1904-10.

[22] Maclntyre $C R$, Chughtai AA, Seale $H$, Richards GA, Davidson PMJljons. Uncertainty, risk analysis and change for Ebola personal protective equipment guidelines. 2015;52(5):899.

[23] Chia S, Koh D, Fones C, Qian F, Ng V, Tan B, et al. Appropriate use of personal protective equipment among healthcare workers in public sector hospitals and primary healthcare polyclinics during the SARS outbreak in Singapore. 2005;62(7):473-7. 
[24] Adams JG, Walls RMJJ. Supporting the health care workforce during the COVID-19 global epidemic. 2020.

[25] Organization WH. Rational use of personal protective equipment for coronavirus disease (COVID-19): interim guidance, 27 February 2020. World Health Organization, 2020.

[26] Emanuel EJ, Persad G, Upshur R, Thome B, Parker M, Glickman A, et al. Fair allocation of scarce medical resources in the time of Covid-19. Mass Medical Soc; 2020.

[27] Person B, Sy F, Holton K, Govert B, Liang AJEID. Fear and stigma: the epidemic within the SARS outbreak. 2004;10(2):358.

[28] Gerbert B, Maguire B, Badner V, Altman D, Stone GJJ. Why fear persists: health care professionals and AIDS. 1988;260(23):3481-3.

[29] Gery GJJPIQ. Training vs. performance support: Inadequate training is now insufficient. 1989;2(3):51-71.

[30] Burns MI, Baylor CR, Morris MA, McNalley TE, Yorkston KMJA. Training healthcare providers in patientprovider communication: What speech-language pathology and medical education can learn from one another. 2012;26(5):673-88.

[31] Sheffer CE, Barone CP, Anders MEJJoeicp. Training health care providers in the treatment of tobacco use and dependence: pre-and posttraining results. 2009;15(4):607-13.

[32] Alanazi A, Alsalmeh M, Alsomali O, Almurshdi AM, Alabdali A, Al-Sulami $M$, et al. Poor basic life support awareness among medical and College of Applied Medical Sciences students necessitates the need for improvement in standards of BLS training and assessment for future health care providers. 2014;21(5):84854.

[33] Oladimeji AM, Gidado S, Nguku P, Nwangwu IG, Patil ND, Oladosu F, et knowledge and practice among healthcare workers in Lagos, August 2014. 2015;20(9):1162-70.

[34] Kak N, Burkhalter B, Cooper M-AJORIP. Measuring the competence of healthcare providers. 2001;2(1):1-28.

[35] Gijare MJSeJoN. Effectiveness of teaching on infection control practices among health care professionals. 2012;2(2):5-9.

[36] Priebe S, Sandhu S, Dias S, Gaddini A, Greacen $T$, loannidis $E$, et al. Good practice in health care for migrants: views and experiences of care professionals in 16 European countries. 2011;11(1):187.

[37] Beech B, Leather PJA, behavior v. Workplace violence in the health care sector: A review of staff training and integration of training evaluation models. 2006;11(1):27-43.

[38] Lan PT, Mogren I, Phuc HD, Lundborg CSJStd. Knowledge and practice among healthcare providers in rural Vietnam regarding sexually transmitted infections. 2009;36(7):452-8.

[39] Haq NU, Hassali MA, Shafie AA, Saleem F, Farooqui M, Aljadhey HJA. Knowledge, Attitude and Practice towards Hepatitis-B: A Comparative Analysis of Hepatitis-B Patients and General Population of Quetta City, Pakistan.18(27):28-37.

[40] Krause G, Schleiermacher D, Borchert $M$, Benzler J, Heinmüller R, Ouattara $K$, et al. Diagnostic quality in rural health centres in Burkina Faso. 1998;3(2):100-7.

[41] Strasser RJFp. Rural health around the world: challenges and solutions. 2003;20(4):457-63.

[42] Shen L-Y, Ochoa JJ, Shah MN, Zhang XJHi. The application of urban sustainability indicators-A comparison between various practices. 2011;35(1):17-29. al. Ebola virus disease-gaps in 